analysis, which will at least save the student trouble, and may possibly suggest an occasional solution. One thing is certain, Abbé Jacquier knows the literature of his subject (Paris : Le Coffre, 1905).

Emery's Theologie Protestante.-Here is a volume which ought to be translated into English. It is divided into three parts. The first part is a general introduction to the study of Protestant theology; the second describes the conditions of that study; and the third contains a bibliography. The first two parts have their value. 'The knowledge is ample, the arrangement is clear, and the judgments are sound. But the chief value of the book lies in the third part. It is the most complete and scientific bibliography of the whole range of theological studies which we have seen, and it is marvellously accurate. We have noted a few misprints, but they are of little consequence- 'E. J. Payre' for 'E. J. Payne,' 'furn' for 'from,' 'lovest' for 'lowest,' all on page 239. Perhaps the translations of Maspero might have been mentioned; they are not identical with the original. Sayce's Gifford Lectures are more to the point now than his Hibberts. 'E. W.,' not 'E. V.,' are Professor Hopkins' initials. In the 'History of Religions' the Greek and Roman lists are defective. Farnell is not mentioned in the one, nor Warde Fowler in the other. The author, who deserves great credit for his work, is Professor Louis Emery of Lausanne. (Lausanne: Rouge, I 905 ; 10 fr.).

La Société Israélite.-In 1899 Professor Frants Buhl published Die socialen Verhältnesse der Israeliten. The volume has now been translated into French by M. Bertrand de Cintré. The translation is a better book than the original. It contains some new matter by Professor Buhl himself, and a good deal of new matter by the translator, who seems to know everything that has lately been done in French, German, or English bearing upon the subject (Paris: Lethielleux, I $905 ; 2.50$ fr.).

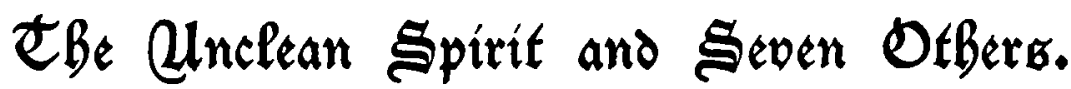

\author{
By the Rev. John Lendrum, M.A., Elgin.
}

\begin{abstract}
'When the unclean spirit is gone out of a man, he walketh through dry places, seeking rest, and findeth none. Then he saith, I will return into my house from whence I came out; and when he is come, he findeth it empty, swept, and garnished. Then goeth he, and taketh with himself seven other spirits more wicked than himself, and they enter in and dwell there: and the last state of that man is worse than the first.'-Matt. xii. 43-45.
\end{abstract}

IT is the strangest of Christ's parables. It has that about it which none of the others has-a touch of the weird and uncanny. It calls up such things as the first scene in Macbeth: 'A desert place. Thunder and lightning. Enter three witches.' There is something lurid in it too, something almost Dantesque.

It was not often that Jesus entered this region of the supernatural. As a rule $\mathrm{He}$ took $\mathrm{His}$ parables and metaphors from nature and the common life of men. The Jews, however, of that time, like the people of India to-day, implicitly believed in evil spirits, and spoke and thought about them not a little. There was, indeed, a special class who made their living through this belief, the exorcists, who professed to have power over evil spirits and to be able to cast them out : and it may be that, when a man they had cured got worse again, or worse than ever, they would excuse themselves by saying that the evil spirit had come back to his old haunt with seven others worse than himself. Such at any rate were the common ideas and popular beliefs of the time, and as Jesus had a momentous message and wished above all to be understood, $\mathrm{He}$ had to make use of popular ideas as well as of the vernacular tongue. However strange these ideas may appear to us, they were thoroughly familiar to those $\mathrm{He}$ desired to reach.

Jesus, it would appear, had been speaking of 
the Jewish people, and especially of their religious leaders the Pharisees, and had dared to declare that though they had once risen above the level of the heathen, they had now fallen very far beneath them. During the Exile they had been weaned from idols. But unhappily this advance in knowledge, instead of making them better men as it ought to have done, had made them worse; for instead of sharing it with others they had kept it to themselves, and become very proud and haughty, looking on themselves as God's favourites and despising the heathen as mere stuff for hell. They separated themselves from others, counting their very touch defiling, laid down all sorts of rules and restrictions, and gave themselves to multiplied washings and purifyings. In a word, their life became like a house swept and cleansed, purged most scrupulously of everything forbidden, garnished with rules and long prayers and broad phylacteries. But it was empty: for it had no love in it, either for God or man. The Pharisees, in making much of rites and rules, forgot the weightier matters of the law. They had lost that humility which is the mother of all the virtues. They professed to worship God, but in truth they had gone back to idolatry; for they had found a new idol in themselves. The unclean spirit of idolatry had been driven out: but now he had come back, and had brought with him seven other spirits more wicked than himself : pride, arrogance, narrowness, hypocrisy, cruelty, greed, hate. Once they had been only idolaters, but now they were full of the subtlest and most unlovely immoralities. That is the meaning of Christ's parable. The unclean spirit of idolatry had been driven out, and wandered in deserts and graveyards, seeking rest and finding none; but at length, as is the way with ghosts and demons, it turned back to its old haunts, and finding its old home swept and garnished and untenanted by any new good spirit, it took other seven worse spirits and entered in and took possession: and the last state of that house was worse than the first.

In this manner Jesus diagnosed the malady of the Pharisees. They had allowed their religion to spoil their morality. That seems a strange, an almost impossible, thing; yet it has happened often, and is a thing against which we have ever to be on our guard. 'There is one proposition,' said Mr. Gladstone once, 'which the experience of life burns into my soul: it is this, that man should beware of letting his religion spoil his morality. In a thousand ways, some great, some small, but all subtle, we are daily tempted to that great sin.' The danger is greatest and most obvious among ecclesiastics, among those who represent religion when it is organized into an institution. They get so devoted to their Church and so absorbed in its interests, that they forget the ten commandments and the law of love. The Roman inquisitors, for instance, tortured their fellow-creatures and burned them at the stake in the name of religion. Archbishop Laud cut off the ears of Puritans, and his successors hunted down the Covenanters. The Jesuit argues that he may do evil that good may come, may lie or plot for the good of the Church and the glory of God. Nor is the evil unknown among modern Protestants. Ministers, and members too, are tempted to do shady things-to cook reports, to raise money in doubtful ways-for the benefit of their Churches. They also give way to jealousy and speak evil of their rivals. They have devoted themselves to religion and cast out the evil spirit of worldliness; but they have not garrisoned their hearts with the new spirit of love, and so the old spirit comes back again and brings with him other spirits worse than himself: intolerance and envy and backbiting and all uncharitableness. As Father Dolling said, "The human are so ungodly, and the godly are so inhuman.'

The great peril besetting the Churchman or the Christian worker is, that he ceases to be humble. He cannot help seeing that he does a good many things which others ought also, but fail, to do; he goes to church, reads his Bible, gives of his means to the Church, and of his time. And the result is that he begins to be proud of himself and censorious and suspicious towards others. There are, too, things he does not do, and these also may make him proud. He does not drink, he does not attend balls or theatres, he does not bet. There is nothing of such things in his life. His house is as it were swept clean of such defilements, and is garnished with prayer-meetings and hymnbooks. But it is empty, untenanted by the spirit of humility which is the spirit of Christ, and so the evil spirit of pride returns, and the last state is worse than the first. He might have been a lovable pagan, but now he is an unlovable Christian.

There are other ways also in which religion- 
religion that is, as Mr. Gladstone points out, not pure as it comes from God, but soiled and besmirched as it passes through us-may spoil and even sap morality. There are those who appear to think, or to live as if they thought, that if only they are right in the matter of religion they can leave morality to look after itself. They are, they say, saved or safe, and then, not of set intention but drawn into it by natural sloth, they take things easily and make no effort after a higher purity. Or perhaps, having caught a glimpse of the love of God in Christ, they allow themselves to make this discovery an excuse for slackness: God is good, they say, and therefore we need not be over severe with ourselves or take life too seriously. Of the gospel as of other great and good things it is true, corruptio oftimi pessima.

But, finally, if such be the malady, where is the cure? Jesus' parable is one of judgment rather than of salvation ; and yet in showing us the mistake it suggests the remedy. The mistake was that the house was left empty. When the evil spirit came back he found it to let. But an empty place is never a safe place. A bare space in a garden fills with weeds; an empty house fills with dirt and cobwebs. Nature abhors a vacuum, and so does the devil. When he finds idle hands he fills them with mischief; when he finds a vacant mind he brings up impurities; when he finds a soul to let he at once becomes the occupier. As Amiel has it, 'In the moral world there is no ground without a master, and the waste lands belong to the Evil One.' We see therefore where lies the remedy. The soul, like a house, should never be without a tenant. And of course the true tenant of the human heart is $\mathrm{He}$ who is its rightful Lord, Christ Jesus. If $\mathrm{He}$ dwell in us $\mathrm{He}$ will save and keep us safe. To have Him within us is to have within us a power that will keep us continually humble and bar out pride, a presence of love that will make us ashamed of envy, a Divine Lord we must needs adore and love. We cannot be saved by Christ at a distance, as if $\mathrm{He}$ were a mere porter who stands by heaven's gate to let us in; if $\mathrm{He}$ is indeed to save us, $\mathrm{He}$ must be near us, $\mathrm{He}$ must be in us.

\section{(X) $\mathfrak{t} \mathfrak{b} \mathfrak{e}$ Eiterary $\mathbb{E}_{\mathfrak{a}} \mathfrak{B} \mathfrak{l} \mathfrak{t}$.}

\section{THE WARS OF RELIGION.}

The Cambridge Modern History. Vol. iii. The Wars of Religion. (Cambridge : At the University Press. I6s. net.)

WE have been writing volumes of apologetics lately. Many of us have been writing. But what is the use of them all? Here comes a volume that is heavy enough to weigh them down and crush them into the earth. If Christianity has been so ready throughout its history to take the sword, what is the use of our now taking the pen? If the Wars of Religion need something like a thousand pages for the most condensed narrative of them, how can we hold up our heads to advocate the Gospel of the Prince of Peace? No indictment that atheist or secularist ever penned is more damaging to the cause we hold so dear than this unprejudiced and unpitying scientific volume.

For the religion is the Christian religion, and its wars are internecine. It is Catholic against Protestant and Protestant against Catholic. And, moreover, the open war is not the worst of it. There is intrigue, incessant and malicious; there is tyranny and assassination; there is massacre, followed by the blasphemy of public Te Deums. This volume had to be written; there would have been a great gap in the 'Cambridge Modern History' without it ; but every follower of Christ must say, Would to God there had been no such volume to write.

In some respects it is the most valuable volume yet issued. It is certainly the volume of most absorbing interest. For the men, and especially the women, who play their part in it are the greatest of modern times. Even the enemy of Christianity will allow that; though he will add that their greatness is in their villainy sometimes, and we have no shield with which to parry his thrust. It was well, too, when the work had to be done, to do it without mercy. The men who write these chapters are authorities on their subject,-in some cases the highest authority living,- and would not condescend ta hide the truth in order to save 